\title{
A Ground Theory Analysis of Fathers' Stress on Rearing of Childre n with Disabilities in Korea
}

\author{
Hyun-Cheol Lee, Teacher, Sawha Elementary School, Changwon-si, Gyeongnam, South Korea \\ *Kyung-Im Han, Dept. of Special Education, Professor, Changwon National University, Changwon-si, \\ Gyeongnam, South Korea, hriver2@changwon.ac.kr \\ Soo-Jin Kim, Dept. of Special Education, Associate Professor, Baekseok University Cheonan-si, Chungnam, \\ South Korea \\ ${ }^{*}$ Corresponding Author
}

\begin{abstract}
This study aims to examine the interview data collected based on understanding and looking at the fathers' experience of raising children with disabilities according to the Ground theory. The subjects of this study were 6 Korean fathers who rear children with disabilities. The research was conducted by indepth interviews and recording of transcripts and data analysis was carried out by on the basis of the Ground theory of Strauss and Corbin. The results of the study are as follows; firstly, the main element in the rearing experience of fathers with children with disabilities was 'hopelessness', and the causal conditions acting on 'hopelessness' were 'devastation' and 'powerlessness'. The situational factors which influenced 'devastation' and 'powerlessness' were 'wife's rearing attitude', in other words 'differences of opinion with wife', 'education values', 'financial status', and 'education system'. Secondly, when we analyzed the situational relations to fathers' rearing experience of children with disabilities, social gaze and educational welfare environment existed in the outermost concentric circles while in the innermost concentric circles, a father himself, a child with a disability and wife's rearing attitude on rearing were appeared to develop by interacting around the father. Thirdly, fathers with children with disabilities were classified into five types, according to the paradigm model which are adopted appraisal standards such as 'the degree of hopelessness', 'wife's rearing attitude', 'education values', 'financial status', 'education system', 'immersion on work', 'the severity of disability' and 'disposition'. In order to alleviate the 'hopelessness' of the fathers of children with disabilities, three measures are required: social gaze, financial status and the improvement of the educational welfare environment.
\end{abstract}

Keywords: Children with disabilities, Fathers, Rearing children with disabilities, Ground theory

Received: 08.12.2020 Accepted: 12.01.2021 $\quad$ Published: 04.02.2021

\section{INTRODUCTION}

Birth of a child with disability causes various difficulties for the whole family, and there are many established research [1,2,3] proved that particularly mothers who are in charge of rearing children in their families feel severe stress on account of their overloaded role burdens for their children. In fact, a father with a strong family responsibility can also expect to receive as much stress as a mother with a child with a disability, however, unfortunately there are not many studies on this topic. Recently, due to the increase of employment of women and the improvement of women's status, and the role sharing of couples in the family based on changing gender roles in terms of gender equality have continuously been discussed and a result of it, there is a growing awareness that fathers should also actively participate in rearing children. In addition, it is reported that when the father is actively involved in rearing children and affectionate to them, accordingly, it affects the degree of the social awareness and gender role development of the children and therefore the father's role in the family is becoming more important than ever [4]. This changing role of fathers can put a lot of stress on fathers by demanding not only economic responsibilities, but also complex activities to promote affection with children. It was already proven that as a support system for a mother, the role of the father with a child with disability plays a significant role in relieving the mother of the child with disability from rearing stress [2] and we can claim that fathers' role is a crucial factor in rearing children with disabilities. Furthermore, the behavior and attitudes seen in fathers' rearing have an impact on the development and problem behavior of children with disabilities [5].

As such, because the fathers' rearing attitude directly affects the development and education of children with disabilities, the role of the father, along with the role of the mother, becomes an essential 
feature in determining the future of children with disabilities. Despite the importance of fathers' role, research on fathers with children with disabilities is very few, compared to studies involving mothers of children with disabilities. In addition, previous studies on fathers' rearing participation of children with disabilities $[6,7,8]$ did not address major topics: for example, what are fathers' difficulties; when do they participate to rear children with disabilities?; how those hardship can be resolved?, and so on Meanwhile, in a qualitative study by in-depth interviews with fathers of children with disabilities [9], it was reported that fathers had psychological issues such as chronic anxiety in the process of rearing children with disabilities. They spent quality time with his family and, at the same time, they strongly aware financial burdens as a head of household. Unlike previous studies, the study dealt with fathers' psychological problems, however, did not explain how the psychological issues emerge and what factors affect them.

Therefore, this study attempted to inspect how psychological problems or difficulties that fathers face while rearing children with disabilities, what they originate from, and the factors affecting such problems and the process of clarifying them on the basis of Ground theory research methodology. The data obtained through this research will provide basic data for the development of programs, which increase reflection on fathers with children with disabilities and their participation in rearing them. This study aims to address the Ground theory analysis of the fathers' rearing experiences of children with disabilities and the research questions are as follows:

First, how can the paradigm model of rearing experiences of fathers with children with disabilities be appeared?

Second, how can the situational model of rearing experiences of fathers with children with disabilities be appeared?

Third, how can the types rearing experiences of fathers with children with disabilities be appeared?

\section{Materials and methods}

\subsection{Subject}

Subjects in this study were 6 fathers of children with disabilities who received inclusive education at an elementary school in Gyeongnam province. The specific characteristics of the subjects are as shown in Table 1.

Table1 Characteristics of subjects

\begin{tabular}{|c|c|c|c|c|c|c|c|c|}
\hline \multirow[t]{2}{*}{ Subject } & \multicolumn{4}{|c|}{ Characteristics of Fathers } & \multicolumn{4}{|c|}{ Characteristics of Children with disabilities } \\
\hline & Age & Education & Religion & $J o b$ & Gender & Age & $\begin{array}{l}\text { Level \& degree of } \\
\text { disabilities }\end{array}$ & Siblings \\
\hline A & 42 & BA & Buddhism & $\begin{array}{l}\text { Self- } \\
\text { employ }\end{array}$ & Boy & 11 & $\begin{array}{l}\text { Develop-mental } \\
\text { disability Level } 2\end{array}$ & $\begin{array}{l}\text { Elder sister } \\
(13), \\
\text { younger } \\
\text { brother (7) }\end{array}$ \\
\hline $\mathrm{B}$ & 48 & BA & None & $\begin{array}{l}\text { Self- } \\
\text { employ }\end{array}$ & Boy & 11 & $\begin{array}{l}\text { Intellectual } \\
\text { disability Level } 3\end{array}$ & $\begin{array}{l}\text { Elder sister } \\
\text { (High } \\
\text { school } \quad 3 \text { rd } \\
\text { grade) }\end{array}$ \\
\hline $\mathrm{C}$ & 37 & $\begin{array}{l}\text { High } \\
\text { school }\end{array}$ & Buddhism & Employee & Boy & 11 & $\begin{array}{l}\text { Intellectual } \\
\text { disability Level } 2\end{array}$ & $\begin{array}{l}\text { Younger } \\
\text { sister (7) }\end{array}$ \\
\hline $\mathrm{D}$ & 43 & $\begin{array}{l}\text { High } \\
\text { school }\end{array}$ & $\begin{array}{l}\text { Tongil } \\
\text { Kyo }\end{array}$ & Employee & Girl & 9 & $\begin{array}{l}\text { Intellectual } \\
\text { disability Level } 3\end{array}$ & $\begin{array}{l}\text { Younger } \\
\text { sister (7) }\end{array}$ \\
\hline $\mathrm{E}$ & 40 & $\begin{array}{l}\text { High } \\
\text { school }\end{array}$ & Buddhism & Service & Girl & 8 & Autism Level 1 & $\begin{array}{l}\text { Younger } \\
\text { brother (7) }\end{array}$ \\
\hline $\mathrm{F}$ & 48 & BA & Buddhism & $\begin{array}{l}\text { Self- } \\
\text { employ }\end{array}$ & Boy & 14 & $\begin{array}{l}\text { Encephalopathy } \\
\text { Level } 2\end{array}$ & $\begin{array}{l}\text { Elder sister } \\
\text { (High } \\
\text { school } \quad 3^{\text {rd }} \\
\text { grade) }\end{array}$ \\
\hline
\end{tabular}

\subsection{Interview questionnaire}

The main questions that will be used in the interview process of this study are as follows; How did you feel when your child was diagnosed with his/her disability?, How were the relationships with your wife 
and other social activities while you are co-rearing?, What are the challenges and rewards of rearing a child with a disability?, What is the stress of siblings on children with disabilities?, What do you think about future problems for children with disabilities?, What do you expect from Korea's special education institutions or society?, and so on.

During the interview process, the researcher sympathized with the opinions of the subjects and maintained positive expressions and attitudes that encouraged the various responses and make the subjects comfortably express their personal thoughts, perceptions and feelings. Interview questions were drawn up through consultations with 1 professor of 12-year teaching experiences in special education major, 2 teachers of 10 -year career in special education fields, and 1 professor of extensive experiences of the Ground theory.

\subsection{Data collection and analysis}

Subjects Before the interviews, the researcher explained the objectives of the study to the subjects in advance, asked for cooperation, and were allowed to interview. After obtaining the permit, the researcher recorded the contents of the interview and documented them. Interviews were conducted at the appointed time and place the subjects agreed to. Whereas A, B, C, D and F subject, except E, were met at the restaurant after work in the evening, E subject worked mainly at night, so the researcher visited his home after school to conduct interviews. Individual interview times ranged from 2 to 3 hours, with interviews covering from one to three times. Basically, the interview was conducted without limiting the interview time or the number of interviews. If necessary, interview was made by telephone for supplement.

Immediately after the interview, the researcher repeated the recording and transferred directly to the computer while listening to the recording. Expressions of the subjects were recorded as they were in the process of transcription, and the personal information on the subjects including names was marked with symbols for confidentiality. Observational records made during the interview were also copied and documented for future reference.

The assessment of this study was carried out according to open coding, axial coding, and selective coding on the basis of Strauss and Corbin's [10] Ground theory analysis method. First of all, open coding is the process of discovering concepts by comparing and analyzing the phenomena that is occurring when the original data are closely examined, and then bringing together similar concepts to form a more abstract category. On the other hand, axial coding is the process of synthesizing data while comprising the linkage between categories displayed in the open coding and furthermore, it links to subcategories as well. It is called an axis due to the fact that the coding takes place around the axis of a category and connects the categories at the sector of attributes and dimensions. Selective coding is the process of further elaboration of the categories presented in the axial coding process and the integration of theories, which, to a greater extent, expands the paradigm around the core categories.

\subsection{Reliability and validity}

In order to increase the reliability and validity of qualitative research, it is necessary to invest a lot of time in the research process, apply the triangulation test, and share the research contents with those who participate in the research [11]. Therefore, in this study, not only in-depth interviews, but also the photographs with the father and the child with disability together, memos and diary records about the child were also recorded in the observation record sheet. Since the main researcher was also a schoolteacher of the subjects' children with disabilities, a variety of data of the children with disabilities were documented as well, so that the relevant data could be utilized for the analysis of this study. In this way, in-depth interviews, photographs and documentary resources, as well as the opportunity to observe the interaction between subjects and children with disabilities during home visits for interviews, were all applied to the triangulation test. All the materials passed after the interview was sent to the subjects by email to confirm the contents, so that they could make a reliable interpretation of the data analysis. Besides that, not only researchers but also 1 professor of 12-year teaching experiences in special education major, 2 teachers of 10-year career in special education fields, and 1 professor of extensive experiences of the Ground theory were participated, in order to enhance the validity of the data analysis process, in particular, including naming categories of transferring materials in decryption process, analyzing situational models, and constructing paradigms and so on.

\subsection{Research ethics}


The following points were considered with ethical awareness of subjects. First, the whole procedure of research was preceded by voluntary consent of the subjects. Second, efforts were made to maintain confidentiality to protect the privacy of subjects. Third, the subject names were treated under the pseudonym, and all interview contents were approved beforehand. Fourth, all the transferred data were shown to the subjects and confirmed by them.

\section{Results}

\subsection{Paradigm model}

The In this study, data analysis on the rearing experience of fathers with children with disabilities revealed 119 concepts, 34 subcategories, and 18 upper categories. The relevant concepts and central phenomena in rearing experience of fathers with children with disabilities are exhibited in Table 2.

Table 2 Concepts and categories of rearing experiences

\begin{tabular}{|c|c|c|}
\hline Sample concepts & Subcategory & Category \\
\hline Diagnosis of disability, Shock, Sadness & Anger & \multirow{2}{*}{ Devastation } \\
\hline Distorted perceptions, Labels, Rumors & Social stigma & \\
\hline $\begin{array}{l}\text { Attention deficits, Crying, Shouting, Emotional disturbances, } \\
\text { Irritation, Echolalia, Self-injury, Non-speech, Over attachment, } \\
\text { Non-interaction, Non-ambulation, Orthopedic deformities, } \\
\text { Cognitive deficits, Overly sexually curious behaviors }\end{array}$ & $\begin{array}{l}\text { Difficult behavior } \\
\text { of child }\end{array}$ & Powerless-ness \\
\hline $\begin{array}{l}\text { Passivity, Social withdrawal, Anxiety about public perceptions, } \\
\text { Over-protectiveness, Lack of acceptance of the child's delayed } \\
\text { development }\end{array}$ & Distortion & \multirow{3}{*}{$\begin{array}{l}\text { Wife's rearing } \\
\text { attitude }\end{array}$} \\
\hline Going out with the child, Encouraging independence & Encouragement & \\
\hline $\begin{array}{l}\text { Denial of diagnosis, Showing the child only videos, Neglect of } \\
\text { siblings }\end{array}$ & Education & \\
\hline Financially stable, Able to bear financial burden & Stability & \multirow[b]{2}{*}{ Financial status } \\
\hline $\begin{array}{l}\text { Failure of business, Debt, Financial difficulties, Separation from } \\
\text { family }\end{array}$ & Instability & \\
\hline $\begin{array}{l}\begin{array}{l}\text { Classroom teacher neglecting the child, Distrust of } \\
\text { therapists/therapy techniques }\end{array} \\
\end{array}$ & Distrust & \multirow{2}{*}{$\begin{array}{l}\text { Education } \\
\text { system }\end{array}$} \\
\hline Considerateness, Positive reinforcement, Accessibility & Trust & \\
\hline $\begin{array}{l}\text { Feeling stupid, Discouraged by results of treatment, Thinking } \\
\text { about suicide, Thinking about emigration, Despair about the future }\end{array}$ & Anguish & \multirow{2}{*}{ Overwhelming } \\
\hline $\begin{array}{l}\text { Being excluded, Being a laughing stock, Worry about child's self- } \\
\text { sufficiency }\end{array}$ & Worry & \\
\hline $\begin{array}{l}\text { Burden on other siblings, Child must be taken care of for their } \\
\text { whole life }\end{array}$ & Burden & \multirow{3}{*}{$\begin{array}{l}\text { Feeling } \\
\text { burdened }\end{array}$} \\
\hline $\begin{array}{l}\text { Wish to live longer than the child, Have a community for the child } \\
\text { after they are gone }\end{array}$ & Wish & \\
\hline High cost for treatment and education & High cost & \\
\hline Marriage, Independence, Becoming a typical person & Expectations & Expectations \\
\hline Guilt, Lack of confidence that other siblings will support the child & $\begin{array}{l}\text { Blaming } \\
\text { Themselves }\end{array}$ & Feeling guilty \\
\hline $\begin{array}{l}\text { Meeting with friends and having company, Being outgoing, Fishing } \\
\text { (hobby) }\end{array}$ & Optimism & \multirow[t]{2}{*}{ Disposition } \\
\hline Anxiety, Timidity, Fatalist & Pessimism & \\
\hline $\begin{array}{l}\text { Wishing for a break, Feeling that there is no time to rest, Working } \\
\text { hard, Working on weekends }\end{array}$ & Working hard & $\begin{array}{l}\text { Immersion } \\
\text { work }\end{array}$ \\
\hline $\begin{array}{l}\text { Mild symptoms, Good communicative ability, Making progress in } \\
\text { treatment }\end{array}$ & Moderation & $\begin{array}{l}\text { Severity } \\
\text { disability }\end{array}$ \\
\hline
\end{tabular}




\begin{tabular}{|c|c|c|}
\hline $\begin{array}{l}\begin{array}{l}\text { Ineffectiveness of treatment, behavioral modification and } \\
\text { education }\end{array} \\
\end{array}$ & Severity & \\
\hline Saving money, Encouraging independence & Preparation & \multirow{4}{*}{$\begin{array}{l}\text { Doing } \\
\text { utmost }\end{array}$} \\
\hline $\begin{array}{l}\text { Constant teaching, Providing the child a variety of experiences, } \\
\text { Focusing on the child's potential to improve, Trying a variety of } \\
\text { medications, Occupational, Physical, and Speech-Language therapy }\end{array}$ & Doing the best & \\
\hline $\begin{array}{l}\text { Compliments, Hugs, Kiss, Physical contact, Playing with the child, } \\
\text { Scolding (not being over-protective) }\end{array}$ & Showing affection & \\
\hline Social welfare center, Church, Private Institution & Using Intuitions & \\
\hline $\begin{array}{l}\text { Feeling it is impossible for the child to be a typical person, } \\
\text { Institutionalization }\end{array}$ & Abandonment & Resignation \\
\hline $\begin{array}{l}\text { Tiredness, Irritability, Feels more comfortable at work than at } \\
\text { home }\end{array}$ & Avoidance & Avoidance \\
\hline $\begin{array}{l}\text { Pride, Composure, Relaxedness, Confidence, Unhurriedness, } \\
\text { Motivated by child, Putting himself in his child's shoes, Do not } \\
\text { mind other people's stares }\end{array}$ & $\begin{array}{l}\text { Psychological } \\
\text { stability }\end{array}$ & \multirow[t]{2}{*}{ Acceptance } \\
\hline Hoping for a miracle, Thinking about the child getting better & Hope & \\
\hline No expectations, Willing to talk about the child, Not reserved & Realistic attitude & $\begin{array}{l}\text { Settlement } \\
\text { for realty }\end{array}$ \\
\hline $\begin{array}{l}\text { Denial, Lack of acceptance, Negative feelings about disabilities, } \\
\text { Cancellation of disability registration }\end{array}$ & Concealment & \multirow{3}{*}{ Denial } \\
\hline $\begin{array}{l}\text { Blames the wife, Fights with the wife, Argues, Taking it out on } \\
\text { other people }\end{array}$ & Blame & \\
\hline Hiding, Not going out, Not meeting with/making new friends & Hide & \\
\hline
\end{tabular}

Based on Strauss and Corbin 10 (1998), a paradigm model of the fathers' rearing experience of children with disabilities is displayed in Figure 1, according to the concept and category of the fathers' rearing experience of children with disabilities illustrated in Table 2.
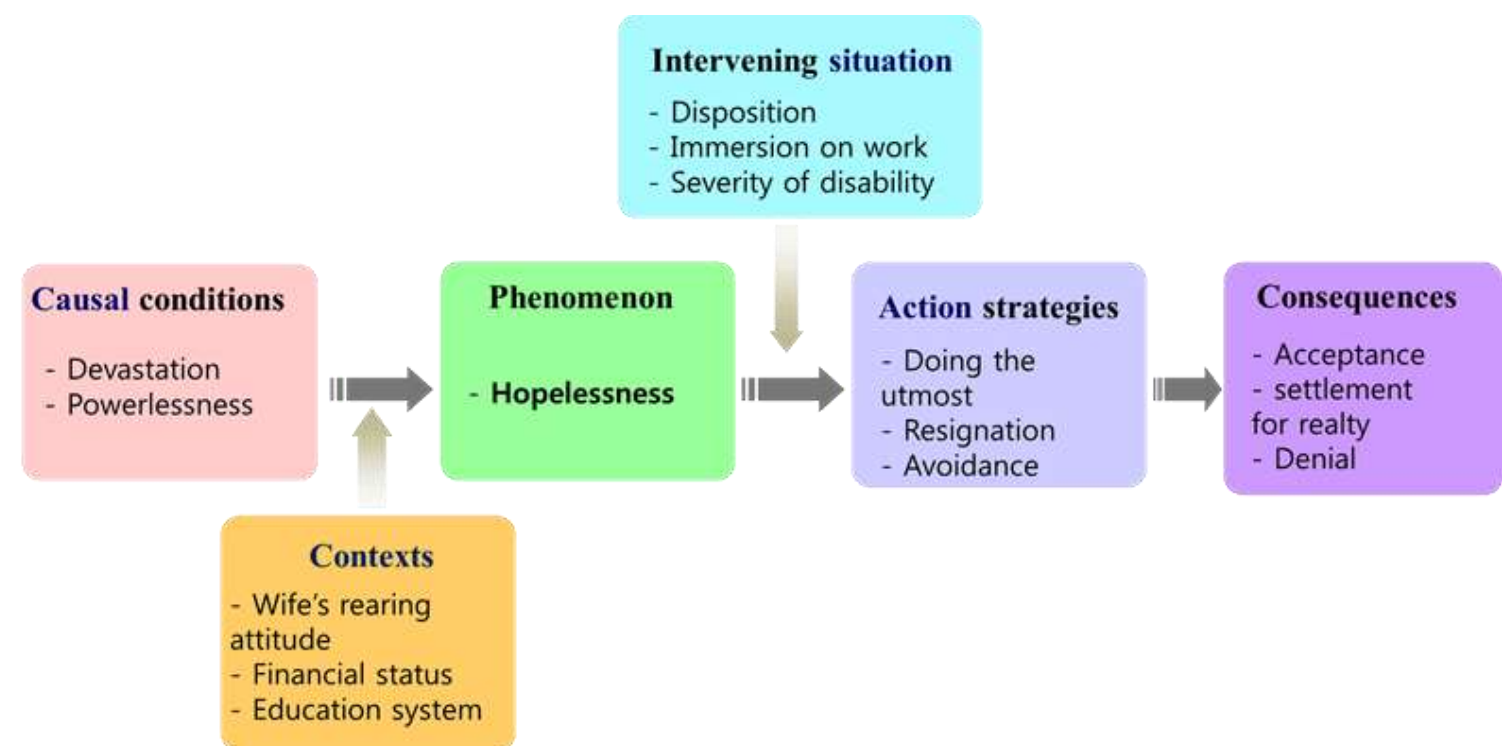

Figure 1 Paradigm model

\subsection{Situational model}

In the outermost concentric circles of the situational relations of fathers with children with disabilities, there were social gaze and educational welfare environment that viewed children with disabilities as negative aspects. In addition, there were financial status such as an increase in burden of education and 
medical treatment costs compared to general children. In the innermost concentric circle, there was a father himself, who reared a child with a disability and therefore the father and his child, and wife's rearing attitude are interacting around the center of father.

On the side close to the subject, there were child and wife's rearing attitude, and on the outer side, there was a society that views the educational welfare environment and disability in a negative way, by contrast, inside the circle, situational characteristics of financial status interacted with each other, and eventually they affected the formation, presentation, and resolution of the "hopelessness". The details are as shown in Figure 2.

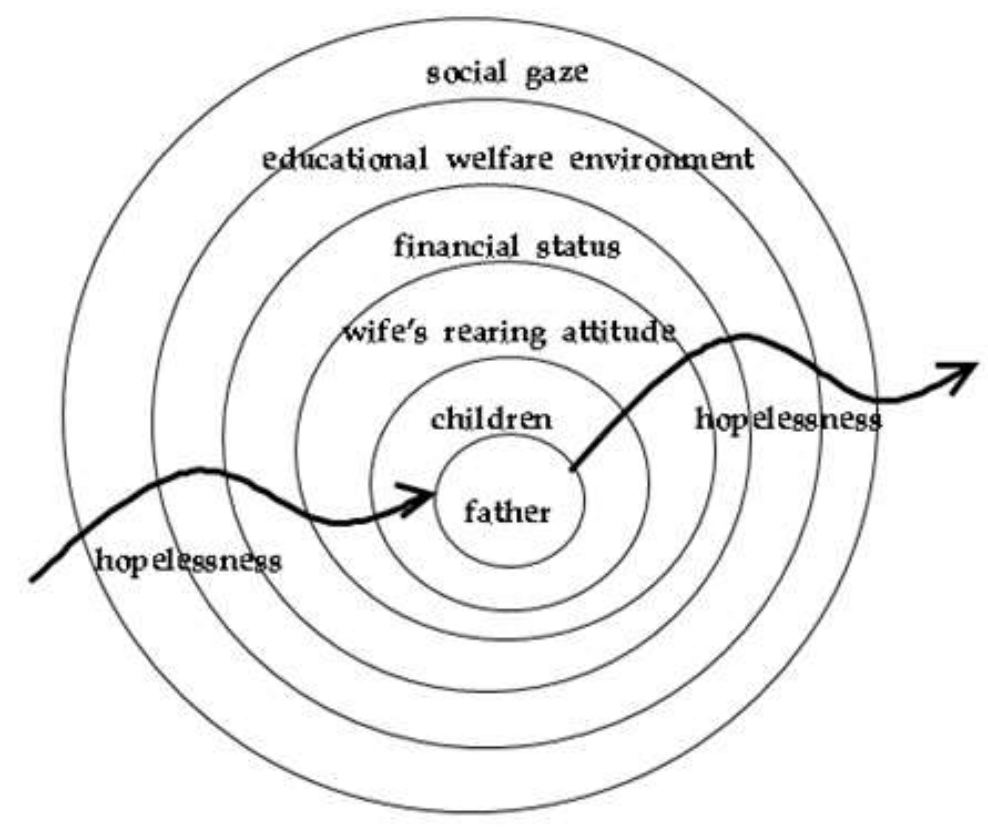

Figure 2 Situational model

\subsection{Types of rearing experiences}

The Based on the hypotheses associated with the 'hopelessness' demonstrated in this study, the following five types can be defined through the interviews of subjects. These types were categorized into the following criteria such as the intensity of 'hopelessness', wife's rearing attitude, education values, financial status, education system, and the disposition of the subject, immersion on work, and the severity of disability.

Type 1: Low intensity of hopelessness, inspiring attitudes from wife, the same education values, abundant financial status, trust in the education system, immersion on work, mild disability if he has an optimistic disposition, it could lead to accept the reality, regardless of either doing the utmost best or avoidance.

Type 2: High intensity of hopelessness, inspiring attitudes from wife, and the same education values, unstable financial status, distrust of the education system, mild disability, immersion on work but if he has a pessimistic disposition, it could lead to settle for reality with avoidance.

Type 3: High intensity of hopelessness, distorted attitudes from wife, different education values, unstable financial status, distrust of the education system, mild disability, immersion on work but if he has an optimistic disposition, it could lead to settle for reality with both doing the utmost effort and resignation.

Type 4: High intensity of hopelessness, inspiring attitudes from wife, different education values, unstable financial status, distrust of the education system, mild disability, immersion on work, but if he has an optimistic disposition, it could lead to settle for reality with both resignation and avoidance.

Type 5: High intensity of hopelessness, inspiring attitudes from wife, different education values, unstable financial status, distrust of the education system, mild disability, immersion on work but if he has a pessimistic disposition, it could lead to deny reality.

As it is shown from this category of types, even if the subject's disposition was optimistic, the severity of disability was mild, the economic condition was not abundant, or he distrusted the education system, it resulted in a settlement for reality. Moreover, if the subject had different opinions with wife regarding 
education values, he did his own best but ended up resignation and settlement for reality.

\section{Discussion}

This feeling of hopelessness strongly speaks of the causal condition between devastation and powerlessness, which are caused by both abnormal behavior of children and social stigma. The tendency of refusing to accept disability in their children and denying to be diagnosed as the disability was widely being reported to be felt by almost all parents of children with disabilities, regardless of the type of disability $[12,13]$. When they found out that their child has a disability, they said they felt a tremendous shock and utter desolation [14]. It is also related to a study on family resilience [8] that fathers were more affected than mothers by improper behavior of children with disabilities, making it much more difficult for them to adapt.

In this research, the degree of hopelessness of the fathers of children with disabilities was weakened when they felt that teacher's attention, praise, and counseling were well carried out. This implicates that the trust in the education system is critical in the major phenomena of the father of children with disabilities. In this study, apart from the education system, it occurred that when financial condition was not sufficient, it added a heavy burdensome to the hopelessness of fathers with disabilities. The fact that financial status acted as the vital factor to central phenomenon, namely hopelessness was indicated in cerebral palsy children [2] and mothers with children with autism, cerebral palsy, and intellectual disability [13].

The influential elements in forming a strategy for coping with the hopelessness of fathers with children with disabilities were 'disposition', 'immersion on work', and 'the severity of disability'. The more optimistic disposition the father with a child with a disability had, the less stressful on rearing experiences he was, and the milder severity the disability was, the less pressure on the rearing stress he had. This result has been illustrated in the previous study such as mothers with children with severe disability has higher rearing stress than mothers with children with moderate disabilities [3] and parents with children with disabilities [15]. The fact that severity of disability affects coping mechanism of parents also arose in the previous study, Korean mothers who rear children with disabilities in the United States [16]. If the disability is severe and the disability is not likely to improve, a coping strategy that expects miracles and relies on religion rather than pragmatic coping was adopted.

In this study, although the severity of disability of children was mild overall, fathers thought disability as social stigma and felt anger, which was different from those of mothers. This result was exhibited in the study on fathers' rearing experience [9] and they were similar in that the father of a child with disability responded more sensitive to the social image of the child's disability than the mother and maintained a passive relationship in a group of friends or at work because of concerns about the negative perception of the child's disability. As such, it can be seen that the father of a child with a disability feels a great burden as the father of the family and at the same time the father of the child with a disability. Besides that, fathers of children with disabilities are struggling with solving financial problems, satisfying the roles and the expectations of the head of household, and at the same time, enduring the lifelong burden of taking responsibility for children with disabilities.

As it is shown from this category of types, even if the subject's disposition was optimistic, the severity of disability was mild, the economic condition was not abundant, or he distrusted the education system, it resulted in a settlement for reality. Moreover, if the subject had different opinions with wife regarding education values, he did his own best but ended up resignation and settlement for reality.

\section{Conclusions}

The central phenomenon of fathers' stress on rearing experience of children with disabilities was the feeling of 'hopelessness' in this study. This 'hopelessness' was expressed as 'devastation', which is caused by the diagnosis of the children's disability, and 'powerlessness' from their abnormal behavior. In this study, however, even though all the children had mild disability and it was possible to take an inclusive education in the general class, fathers perceived child's disability as severe case. It should be noted that this might be related to the problem of how the parent perceived the child's disability separately from the objective disability of the child. This pinpoints that further research will be required. This study illustrates that in a situation where the education values with the wife are different and wife's rearing attitude is distorted, the father feels more stressed by different education values with his wife than the stress of raising a child with disability. This suggests that education and treatment of children with disabilities are important, but at the same time that parents should be thoroughly educated together in terms of disability variables. It is not just a matter of entrusting rearing to a wife alone, but also it is a matter of 
raising the necessity for developing psychological counseling and education programs that enable fathers and mothers to properly recognize the conditions of children with disabilities and to form common education values and to have shared responsibility.

\section{Acknowledgements}

The authors of this study would like to thank the parents who participated in the in-depth interviews.

\section{References}

[1] Kim SH, Han KI. Analysis of child rearing experiences of mothers with progressive muscular dystrophy. Study of Delay, Duplicate, and Health Disability. 2013;56(1):187-213. Available from: http://www.dbpia.co.kr/journal/articleDetail?nodeId=NODE07489828

[2] Han KI, Kim JH. Analysis of parenting experiences of mothers with cerebral palsy. Education for Infants with Multiple Delays. 2007;49(1):277-297. Available from: http://www.riss.kr/search/detail/DetailView.do?p_mat_type=1a0202e37d52c72d\&control_no=8f8 $38 \mathrm{bfa} 224445 \mathrm{ef}$

[3] Lee HS, Ryu KH, Han KI. Stress and coping behaviors of mothers with children with disabilities and their characteristics. Special Child Education Research. 2007;9(4):271-294. Available from: http://www.riss.kr/search/detail/DetailView.do?p_mat_type=1a0202e37d52c72d\&control_no=3f9 7f863557fec45ffe0bdc3ef48d419

[4] Kim HY, Park SG, Ji JH, Seong JY, Shin MS. Relationship between father's stress and child care. Journal of Human Ecology. 1997;30:80-84. Available from: http://www.riss.kr/search/detail/DetailView.do?p_mat_type=1a0202e37d52c72d\&control_no=589 $69 \mathrm{~b} 5 \mathrm{c} 6382 \mathrm{e} 26 \mathrm{a}$

[5] Fan, X, Chen, M. Parental involvement and students' academic achievement; A meta-analysis. Educational Psychology Review. 2000;13:1-22.

[6] Jeong SD, Kim GE. A study on the relationships among attitudes toward disabilities. Family Beliefs and Fathers' Involvement with Disabled Children. 2010;15(2):85-104. Available from: https://www.kci.go.kr/kciportal/ci/sereArticleSearch/ciSereArtiView.kci?sereArticleSearchBean.art iId=ART001454318

[7] Jung JA, Hwang HW. The effects of positive significance and social support on parenting participation in fathers of children with developmental disabilities. Journal of Korean Council for Children and Rights. 2016;20(1):21-47. Available from: http://scholar.dkyobobook.co.kr/searchDetail.laf?barcode=4050025363835

[8] Kim GE. The effect of family resilience on the parenting participation of fathers with children with disabilities. Korean Welfare for the Disabled. 2006;4:167-202. Available from: http://scholar.dkyobobook.co.kr/searchDetail.laf?barcode $=4050025269238$

[9] Kim JY, Yoon HJ. A study of father's parenting experiences for children with disabilities. Special Education. 2013;12(3):333-356. Available from: http://www.riss.kr/search/detail/DetailView.do?p_mat_type=1a0202e37d52c72d\&control_no=d82 710774a03c21 effe0bdc3ef48d419

[10] Strauss A, Corbin J. Basics of qualitative research: technique and procedures for developing Ground Theory. 2nd Eds. Sage publication Inc.; 1998. p. 101-121, 123-126, 143-161.

[11] Carter N, Bryant-Lukosius D, DiCenso A, Blythe J, Neville AJ. The use of triangulation in qualitative research. Oncology Nursing Forum. 2014; 41(5): 545-547.

[12] Oh SC. The effectiveness of the coping strategies training program for parents of children with cerebral palsy. Korean Journal of Physical, Multiple, \& Health Disabilities. 1995;26(1):23-42. Available from: http://kiss.kstudy.com/thesis/thesis-view.asp?key=1441054

[13] Han KI, Song MS, Park CS. Parenting experiences of mothers with children with disabilities. Research on Emotional and Behavioral Disorders. 2003;19(3):55-66. Available from: https://www.kci.go.kr/kciportal/ci/sereArticleSearch/ciSereArtiView.kci?sereArticleSearchBean.art iId=ART000877045

[14] Hanson, MJ, Lynch EW. Understanding families: approaches to diversity, disability and risk. MD: Paul H. Brooks. 2004.p.90-91.

[15] Khamis V. Psychological distress among parents of children with mental retardation in the United Arab Emirates. Social Science \& Medicine. 2007;64:850-857.

[16] Han KI, Song MS, Cho E. Korean parents with child with disabilities in the United States, Child Care Experience, Special Child Education Research. 2014;16(2):99-126. Available from: 
http://kiss.kstudy.com/thesis/thesis-view.asp?key=3250017 